\title{
The effectiveness of mendong plaited rope production: the design of automatic mendong rope twisting machine
}

\author{
Duwi Leksono Edy ${ }^{1, *}$, Widiyanti ${ }^{1}$, Fahru Riza $^{1}$ and Kharis Sofia Sari ${ }^{1}$ \\ ${ }^{1}$ Mechanical Engineering Department, State University of Malang, 65145 Malang, Indonesia
}

\begin{abstract}
This article discussed the latest and most efficient machine design in rope from mendong. This machine design is multifunctional. There a plenty of available machines but many people were constrained in production process which needed more time because the rope making process went through several steps. The engine work is not maximal, the production of minimal mendong rope. So that the demand for handicrafts from mendong ropes in the market cannot be fulfilled. Setting off from this problem, designing machines with the latest technology with a work system that needs to increase the production of craftsmen and the economic level of the community in Blayu, Wajak District, Malang Regency, Indonesia.
\end{abstract}

\section{Introduction}

Indonesia is an agricultural country where agricultural sector holds an important role in promoting national economy. This can be supported by natural resources and the people's condition in which most of them are farmers (Siringo, 2012).

According to Utami (2010), the development that is oriented on economic development plays more role in people's participation in natural resources utilization development. People's engagement sector can be measured from their participation in the implementation of the obligation without considering the people's rights. The involvement of people's component tends to imply that people are obliged to do the government program even though it often does not correspond with people's will.

Fadeli (2001) explained that development activities, emphasizing on government programs in conservation aspects also environment utilization which confirms the suitability of the development program, pay attention to people's aspiration so they can create the expected change such as the existence of new employment and ability to improve standards of living of a group of people who are able to see and take working opportunities.

Economic development especially in East Java has a primary sector which is agriculture sector. Agriculture has the highest potential to be developed as it has a high linkage with

\footnotetext{
*Corresponding author: leksono_duwi@yahoo.co.id
} 
other districts and cities in East Java. Therefore, by improving the agriculture sector, it will give a positive impact in improving each region acceptance, employment provision, additional score gain, and competitiveness in various regions.

District of Malang is one of the districts in East Java which has a potential to develop the agriculture sector. From the PDRB data, agriculture sector in the district of Malang improved steadily each year from 7,439.2 billion rupiah in 2011 to 8,400.3 billion rupiah in 2015.

Creative economic development which has creative industry in it is the current government's prominent jargon. The current government believes that if the creative economic is developed, it will give positive impact for people.

Depdag (2007) arranged a development plan in facing rivalry in creative economic field divided into 14 sectors; they are advertising, architecture, arts market, crafting, design, fashion, film-video and photography, interactive games, music, performing arts, publishing and printing, computer service, radio and television (Simatupang, 2008). In its development, there are some additional industrial sectors working as the creative industry incubators which are agribusiness, culinary, and automotive (Murniati, 2009).

The government's effort has to be supported by the availability of the raw materials, trainings, and development for the creative industrial performers, promotion and marketing performed in an integrated manner, also a list of other steps that can expand the creative industry.

Mendong plant is one of the commodities cultivated to fulfill the industrial needs and become a good prospect especially in creative industry world since it has a high sale value and good marketplace in crafts. Many crafts can be made from this plan such as mat, rope, sandals coating, household furniture coating, house ornaments, rope, textile, and textile product (Azis, 1999). Mendong (Fimbristylis globulosa) is a type of grass that grows in wetland areas and usually grows up to more than $100 \mathrm{~cm}$ in the length. Traditionally, the mendong straws have been used for rope, mats, and other product like baskets, furniture, and handbags ( H.Suryanto.2016).

The District of Malang is one of the regions cultivating Mendong especially in Wajak sub-district. In Wajak, there is one superior product which is Mendong crafting business. Wajak region has enough and even pouring water resource. This condition is suitable for cultivation of Mendong. The habitat of Mendong is a wet field like rice field or swamp, a muddy and watery place. In Wajak, Mendong is peculiarly used to make mat, rope, and plaited crafts.

To increase the production of mending farmers, optimization on the factor production can be used effectively and efficiently. The production factors mentioned include the use of efficient production machine.

\section{Literature Review}

Automatic mendong rope twisting machine is a production machine designed with simple system and shape to make the time and cost production more efficient. The design of mendong rope twisting machine has basic components. Some components work in order in one system.

There are several production processes with mendong plant as its basic material. The overall production process can be illustrated as at Figure 1. 


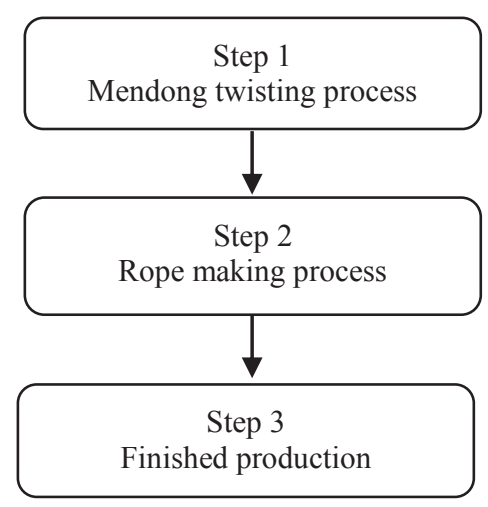

Fig. 1. Production Process

Overall, the explanation of the production process is as follow:

\section{Step 1}

In step 1 of the production process, a twisting of mendong consisted of 4 seeds of mendong into 1 seeds mendong is done.

\section{Step 2}

The second step require 2 twisted mendong. This process results in 1 mendong becoming a rope.

\section{Step 3}

In the finished production process, the mendong is ready to be used as the staple of plaited mendong crafts.

\section{Problem Statement}

The mendong plant is the basic material for plaited products. The improvement of production is the main aspect in fulfilling the demands in the market. Each month the local and international demand is very high. It is caused by the good crafts and good taste of arts of the mendong. The improvement of production process is affected by some aspects, one of them is the working system of the production machine.

The current problem happening in the process is the ineffectiveness of the production process so it takes a quiet long time for the production. There are three processes which are twisting the mendong, rolling the twisted mendong, and making the rope. The three processes require a long time so the production process is inhibited and fulfilling the demand of the market takes a long time.

From the problem above, a multifunctional machine was created with the aims of:

- More efficient production process

- Decreasing the high production cost

- Fast production time allotment.

\section{Method}

The mendong rope twistin machine has multi functions in production process. The working principals in this machine happen in three sequence processes. In the conventional process, three processes are done separately. The first process is the mendong raw material with 0.5 $\mathrm{cm}$ diameter twisting process. The machine detailed explanation is shown at Figure 1, 


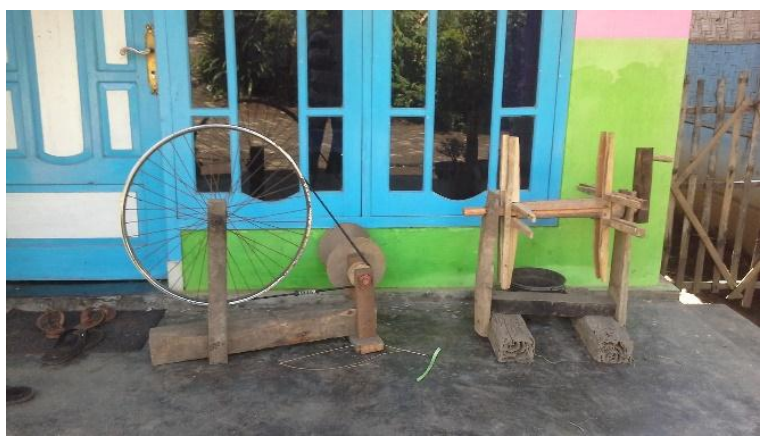

Fig.2. The Conventional Twisting Machine Step 1

After the first step, the twisted mendong is rolled.

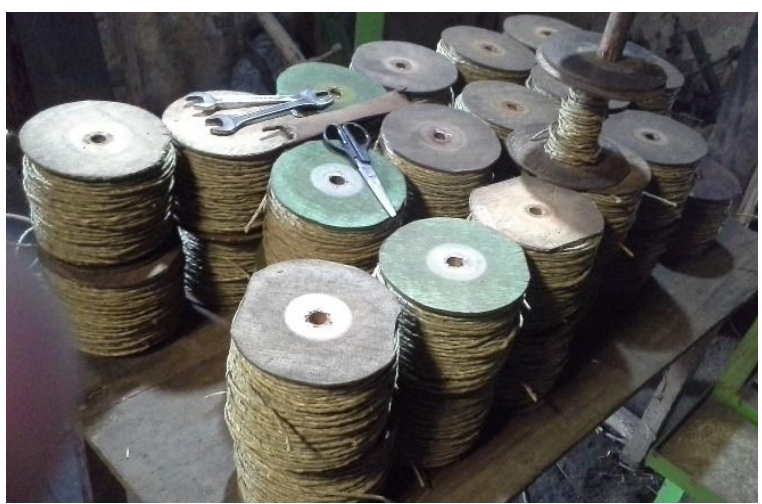

Fig. 3. The Rolling of Mendong Step 2

The following process is therolling process. The twisted mendong is rolled into a rope. This process is done by an electric machine.

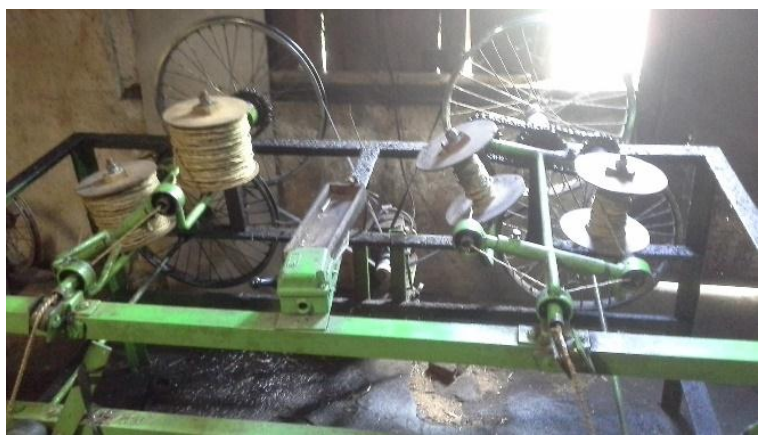

Fig. 4. The Making of Tampar Mendong Step 3

The explanation of the mendong twisting process happen in several processes. With the latest technology, a more efficient mendong rope twisting machine is created. The starting process in this machine happen with the gears which are rotated by a motor resulting in mendong's twist with $0.5 \mathrm{~cm}$ diameter consisted of $4 \mathrm{pc}$ mendong. The second process happens with two gears working system working at the same time. This process consisted 
of two mendong's twists with $0.5 \mathrm{~cm}$ diameter twisted into one twist making a mendong with $1 \mathrm{~cm}$ diameter. The detailed machine design is Figure 4,

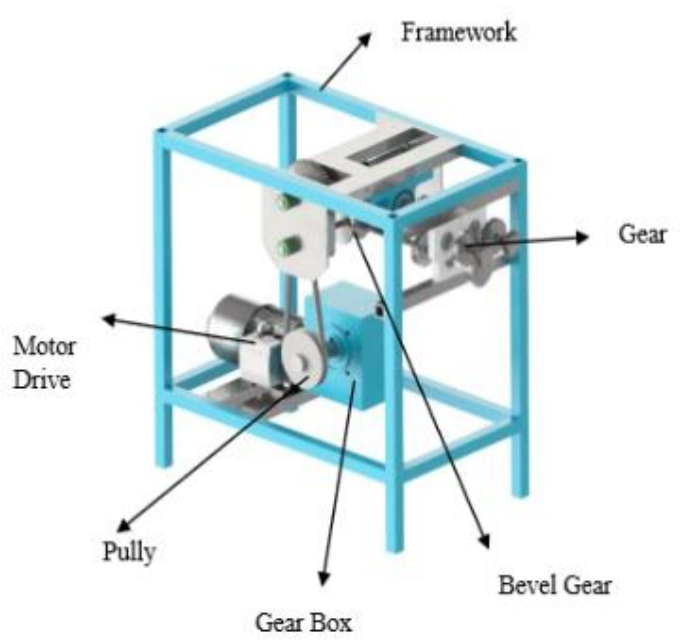

Fig. 5. Design Mechine

\section{Analysis and Design Consideration}

Once the engine design has been selected, and machine analysis is performed. All of these help resolve decisions in terms of material selection used to fulfill the project. Mathematical analysis explains in detail the forces that the machine will need for operation. Once strength is established, analyze the component dimensions to ensure they manage the given style.

\subsection{Von Mises Stress}

Von Mises stress from static structural stress analysis of Finite Element Analysis (FEA) simulation results in engine conditions loaded with load force of 438,648 N supported on the construction of engine framework that is in the form of gear box, motor, gear, pulley, bearings and gear mount components or shaft holder.

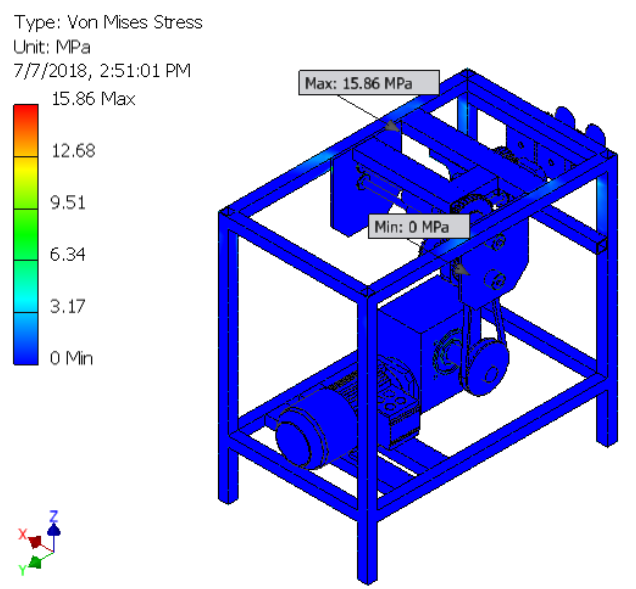

Fig. 6. Von mises stress analysis result 
in Figure 5 the overall design is depicted in blue colors that are valued under 3.17 MPa, from this value it can be seen that the design structure of this machine is safe to use and operate. Von Mises is said to fail, if the maximum value of Von Mises stress material is more than or exceeds the strength of the material. The maximum value of von mises stress is $5.86 \mathrm{MPa}$, the maximum value of von mises stress lies in the component of the shaft support plate.

\subsection{Safety Factor}

The value of safety factor is obtained from comparison between yield strength of construction material $(250 \mathrm{MPa})$ divided by maximum stress von mises. In Figure 6 it can be seen that all parts of the machine have a high safety factor value of 15 , it can be interpreted that the construction is not affected significantly due to the maximum von mises stress that occurs.

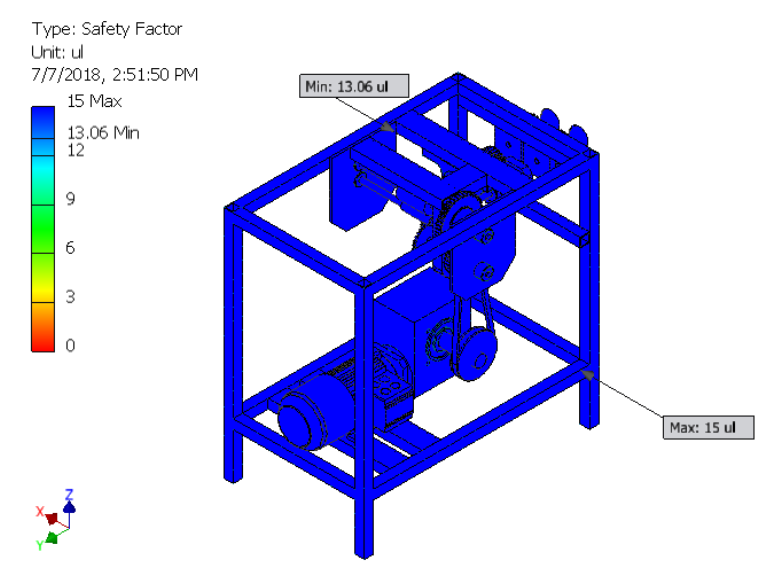

Fig. 7. Safety factor analysis result

the simulation results can be concluded that the minimum safety value of ' 13.06 is more than the value of 1 definition of failure or permanent yield (Waguespack, 2014). Then it can be said that the engine structure to withstand the load that works on the engine frame.

\subsection{Displacement Analysis}

Figure 7 is the result of displacement analysis of stress analysis. The result of simulation displacement on partial structure in blue color with value below $0.007 \mathrm{~mm}$, on the other side shows light blue color with value $0.007-0.015 \mathrm{~mm}$. Maximum displacement is 0.037 $\mathrm{mm}$ telem on the component of the lower gear, which is indeed the component is directly related to the driving pulley. 


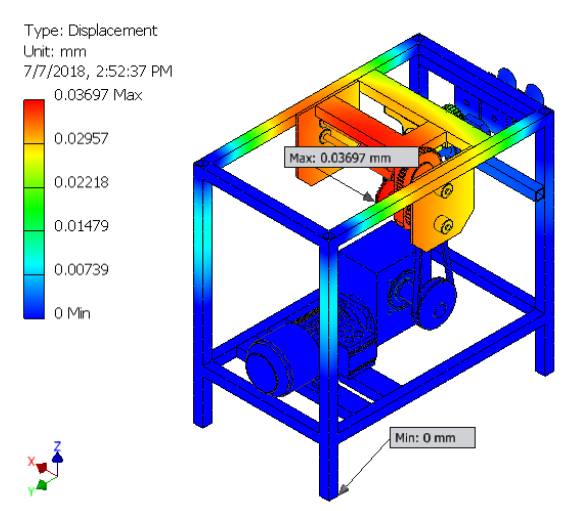

Fig. 8. Displacement analysis result

\section{Testing and Discussion Result}

The production process of mendong in Blayu village, Wajak, each month reaches $\pm 500-$ 700 per month. That result is still insufficient in fulfilling the market demand. This is the problem found in Blayu village.

After we communicate with the businessman and plaited mendong crafter, we result in a solution aimed to improve the production of plaited mendong. The appropriate technology having a multifunction work is expected to be able to increase the production in each month.

By using the automatic electric plan and design, the production target in each month can reach $\pm 3000-5000$ per month with production accumulation reaching 8 meters per hour. The latest and most efficient machine design is expected to be able to increase the production of plaited mendong and improve the financial of Blayu people.

\section{Conclusion}

Based on the explanation and the result of the discussion, it can be concluded that by using the mendong plaiting machine with multifunctional work can increase the production of UMKM mendong Blayu village production in Wajak, Malang District, East Java, Indonesia.

\section{References}

1. Siringo \& H. Berlina, Journal of Economics and Finance, 2488 (2012)

2. A. Taufik, Institut Pertanian Bogor, (1999)

3. Fadeli, C. Natural Tourism Planning, Yogyakarta: Universitas Gadjah Mada.

4. H. Suryanto, S. Solichin \& U. Yanuhar, in Fiber Plants - Biology, Biotechnology and Applications, 1st ed., K. G. Ramawat and M. R. Ahuja, Eds. Springer, 1-17 (2016)

5. U. Utami, Journal of Community and Village Development. Universitas Indonesia. 11 (2011)

6. T. M. Simatupang, Institut Teknologi Bandung (2008)

7. D. E. Murniati, National Seminar on the Role of Vocational Education in the Development of Creative Industries. Department of PTBB FT UNY (2009) 